\title{
Middle Neolithic farming of open-air sites in SE France: new insights from archaeobotanical investigations of three wells found at Les Bagnoles (L'Isle-sur-la-Sorgue, Dépt. Vaucluse, France)
}

\author{
Ana Jesus $^{1} \mathbb{D} \cdot$ Georgina Prats $^{1} \cdot$ Franziska Follmann $^{1} \cdot$ Stefanie Jacomet $^{1} \cdot$ Ferran Antolín $^{1}$
}

Received: 27 January 2020 / Accepted: 19 June 2020 / Published online: 18 September 2020

(c) The Author(s) 2020

\begin{abstract}
Previous reviews of Middle Neolithic agricultural practice (4400-3500 cal BC) in southern France have highlighted a change in crop assemblages after $4000 \mathrm{cal} \mathrm{BC}$, with a reduction of naked wheat and an increase of emmer and partly of einkorn. The recent investigation of three wells from the site of Les Bagnoles (4250-3800 cal BC) in the periphery of the southern Rhône valley yielded an unprecedented amount of waterlogged uncharred and charred plant macro remains that offer new insights into crop diversity and its changes over time. The results from the wells at Les Bagnoles were compared with other dated sunken features from open-air sites (in contrast to caves and rock shelters), with the aim of identifying patterns suggesting changes in the crop spectra between the early (MN1) and late (MN2) Middle Neolithic phases from taphonomically comparable contexts. The results from Les Bagnoles demonstrate that oil crops and pulses are underrepresented in dry sites and that they were a significant part of Middle Neolithic agriculture. They also indicate an increase in the representation of einkorn (instead of emmer) during MN2 that is also visible in other open-air sites. The comparison of the archaeobotanical results with silo storage capacity values as a proxy for average production capacity per household leads us to propose a possible drop in naked wheat productivity and opens new questions in factors affecting crop choice at the beginning of the 4th millennium cal BC.
\end{abstract}

Keywords Pits $\cdot$ Neolithic storage $\cdot$ Crop diversity $\cdot$ Wells $\cdot$ Waterlogged preservation

\section{Introduction}

Middle Neolithic farming practices in southern France have received the attention of archaeobotanists in the last decades, either as site publications, reports or as reviews at a site scale (Phillips 1982; Marinval 1988a, b, 2003; Heinz et al. (1992; Beeching et al. 2000; Savard 2000; Thiébault et al. 2004; Vital et al. 2007; Martin et al. 2016; Bouby

Communicated by C.C. Bakels.

Electronic supplementary material The online version of this article (https://doi.org/10.1007/s00334-020-00793-z) contains supplementary material, which is available to authorized users.

Ana Jesus

anaclaudia.sousajesus@unibas.ch

1 Department of Environmental Sciences, Integrative Prehistory and Archaeological Science (IPAS), University of Basel, Spalenring 145, 4055 Basel, Switzerland et al. 2018; Antolín et al. 2020b), but large-scale detailed analyses at a context level have not been undertaken to date. One of the reasons that explain this broad-scale approach is the existence of much data in old reports resulting from grab or non-systematic sampling, sieving with large mesh sizes, and/or works where the methodology is not clearly presented. However, efforts are being made to undertake a more accurate regional study of the Middle Neolithic period in south-eastern France (Martin 2014). The last review by Martin et al. 2016 suggests important changes in the crop spectrum which occurred at a site scale after $4000 \mathrm{BC}$, with a reduction of naked wheat in favour of glume wheats, particularly emmer. One of the questions raised in that paper concerns the type of naked wheat that was grown in the Mediterranean areas of France, whether the tetraploid or the hexaploid type. The lack of chaff remains at the investigated sites made it impossible to characterise this crop to its ploidy level. The second question is about the reasons for the changes in crop choice. According to several authors (Delhon et al. 2009; Beeching and Brochier 2011, pp 146-150), 
the expansion of farming before $4000 \mathrm{BC}$ may be due to a climatic stabilisation. Conversely, several hypotheses have been proposed for the period after $4000 \mathrm{BC}$, such as increased soil erosion due to the possible human use of fire or natural fires; or a period of global cooling and hydrological changes (Magny and Haas 2004; Delhon et al. 2009, p 62) along with a regional demographic decline (Beeching 2002; Berger et al. 2019). At this juncture, a site with excellent preservation of archaeobotanical remains brought a new perspective to the existing dataset. Les Bagnoles (L'Isle-sur-la-Sorgue, Dépt. Vaucluse, Provence-Alpes-Côte d'Azur) revealed three wells with waterlogged deposits that contained charred and uncharred plant remains from three different time spans during continuous occupation within the Middle Neolithic period, hence being the perfect site to target both of the questions posed above.

The Middle Neolithic of southern France is usually divided into two phases: Middle Neolithic 1 (MN1) 4400-4000 cal BC and Middle Neolithic 2 (MN2) 4100-3500 cal BC (van Willigen et al. 2020b). MN1 is composed of different groups of communities defined by pottery styles such as pre-Chassey or early Chassey culture (Gernigon 2014), with sites such as Pendimoun (Binder et al. (1993), Giribaldi (Thiébault et al. 2004) and Fontbrégoua (Savard 2000). Another group is Saint Uze, with sites such as Plateau Raverre (Beeching et al. (1997), Gardon (Bouby 2009) and Chenet des Pierres (Martin et al. 2008); another pottery typology group is Montbolo, with the site Montou as one example (Buxó 2006). In this period, the open-air sites are close to alluvial terraces and open areas, sites such as Plots, Abri Font Juvenal, Le golf Auriac, Le Crès, Encombre, Saint Antoine and Le Pirou (Martin et al. 2016). The Middle Neolithic 2 period (4100-3500 cal BC) includes pottery style groups attributed to Late Chassey, La Roberte (van Willigen et al. 2014) and Neolithic Moyen Bourguigon (Sénépart et al. 2014), from different sites such as ZAC Saint Antoine II and Le Moulin (Martin et al. 2016). All the sites mentioned above have provided archaeobotanical data.

Over 70 Middle Neolithic sites with archaeobotanical data are known from the whole of France, among which the most frequent ones are open-air sites followed by cave sites (Martin et al. 2016). In this paper, we will focus on the open-air sites since the Les Bagnoles site is included in this category, while cave sites were excluded from the analysis due to their different taphonomy and uses (Martin 2014; Jacomet 2020). Open-air sites of this period in southern France have no clear evidence of structures that define the extent of the site, and they are mainly composed of negative (sunken) features in the subsoil such as pits, silos (storage pits) and wells (Thirault and Remicourt 2014; Giligny and Sénépart 2018). Evidence of water management, such as wells, starts to be more frequent during the Neolithic period, and is normally associated with a more sedentary life and a more fixed economy such as agriculture and animal husbandry. Several Early Neolithic wells have been found in more northern parts of Europe (Tegel et al. 2012) and in southern France (Thirault and Remicourt 2014, p 236), and their archaeobotanical investigation has provided important additions to the available information on farming practices in those areas (Herbig et al. 2013).

Underground silo pits are the most common type of storage technology found archaeologically around the Mediterranean (Sigaut 1988). Therefore, they are the only features that allow large-scale quantitative analyses of volumetric capacity informed by consideration of silo shape, to provide insight into the cultural, technological and economic organisation of agricultural societies (Prats et al. 2020). There have been few systematic silo studies on Neolithic sites, although pioneer research was done in our study area by Beeching et al. (2010). A systematic study of prehistoric silo pits was done in previous work focused on Catalonia, north eastern Iberian Peninsula (Prats 2017), and we are currently expanding it to other areas including southern France (Antolín et al. 2018). During this work, it was observed that silo capacities in the Neolithic are significantly lower than in later periods in prehistory and that there is a progressive increase in their mean volume from $580 \mathrm{~L}$ in the Early Neolithic to 800 and $950 \mathrm{~L}$ in the Middle and Late Neolithic respectively. Archaeological and ethnographic research has tended to establish a direct relationship between storage capacity and immediate field production, that is to say, the yield of each harvest and the area which was cultivated (for example, Sharples 1991).

Consequently, we decided to work with the mean storage capacities per period as a proxy for productivity, thus avoiding the interpretation of single values. The results from Catalonia were interpreted as an increase in production capacity of households during the Neolithic period (Prats et al. 2020). Nevertheless, this interpretation is never straightforward, since the stored volume always depends on the type of crops and the form in which they were stored, so that naked wheat was usually stored as a cleaned product, but glume wheats usually as spikelets, which makes them more pest-resistant (Jones et al. 1986). Whole spikelets occupy at least double the volume of cleaned grain, as experiments suggest (Alonso et al. 2013; Cappers et al. 2013) and hence the storage space needed is larger for the same amount of grain. Since a change in crop assemblages toward more glume wheats has been detected in our study area according to previous work, the mean capacity values of underground storage pits may show a consequent increase in volume during phase MN2, if household productivity and the organisation of storage stayed constant during this change.

In this paper, the archaeobotanical data from the three wells at Les Bagnoles are presented and these results are then integrated into a regional contextual comparison of archaeobotanical evidence from taphonomically comparable 
features such as pits/silos and wells. The goals of this comparison are to reflect on the representativeness of the data generated by the wells at Les Bagnoles; to understand if there is any pattern of distribution between the various crops at the structure level and to see if there was any change with time between MN1 and MN2. In order to discuss potential causes for changes in farming practices during the Middle Neolithic period, we will include an evaluation of underground storage capacity as a proxy for productivity.

\section{Materials and methods}

\section{The Les Bagnoles site}

The archaeological site of Les Bagnoles is located $2.5 \mathrm{~km}$ southwest of L'Isle-sur-la-Sorgue, Dépt. Vaucluse (Fig. 1), on alluvial soils (Sargiano et al. 2010), within a mosaic of plant communities that go from woods by rivers to wet and dry grasslands as well as ruderal vegetation connected to human impact on the landscape (Jacomet 2020). The site was found in 2006 and excavated scientifically between 2012 and 2015 by Landesmuseum Zürich (Swiss National Museum) and the Universities of Basel and Aix-Marseille (van Willigen et al. 2020a). Several phases of occupation were detected, dated to the Middle Neolithic, Bronze Age, Iron Age, Gallo-Roman and modern periods, mainly as negative structures, such as pits, silos, post holes and wells (site plan, ESM Fig. 1, well 250, ringed in red, above, and wells 990 and 994 below; Denaire and van Willigen 2020). In this paper, we will focus on the three Middle Neolithic wells (structures 250, 990 and 994) dated between 4250 and $3700 \mathrm{cal}$ BC because they offer a unique record of crop remains (well sections, ESM Fig. 2). All wells lacked any sort of lining.

The wells were dug in spits (artificial levels) of 20 to $10 \mathrm{~cm}$. Structure 250, more than $3 \mathrm{~m}$ deep, was excavated in two halves (ESM Fig. 2a). The southern half was dug first, in spits of $15-20 \mathrm{~cm}$, while the northern half was dug in spits of ca. $10 \mathrm{~cm}$. Due to the higher precision of the sampling, the northern half was prioritised. Additionally, samples from a test core were also investigated. Permanently waterlogged deposits were reached at a depth of $2.5 \mathrm{~m}$, although the water table could have been often much higher in the past. Structure 990 was $3.3 \mathrm{~m}$ deep and the lower part of the well was sampled in spits of $10 \mathrm{~cm}$ for the whole well, but not in halves, due to the difficulty of working at such a depth (ESM Fig. 2b). A core sample was also taken. Finally, Structure 994 was more than $3.1 \mathrm{~m}$ deep and sampled in the same way as well 990 (ESM Fig. 2c). The archaeobiological sampling of wells 990 and 994 concentrated on the waterlogged layers, and all the sediment was kept for further scientific analyses. The wells contained large amounts of pottery, flint, animal bones and dung, suggesting daily refuse deposits (Antolín et al. 2020a, c).

Well 250 is radiocarbon dated to ca. $4250-4050 \mathrm{cal}$ BC, well 990 to 4050-3980 cal BC and well 994 to 3940-3780 cal вс (Table 1; Martínez-Grau et al. 2020).
Fig. 1 Map showing all the sites in southern France discussed in the paper

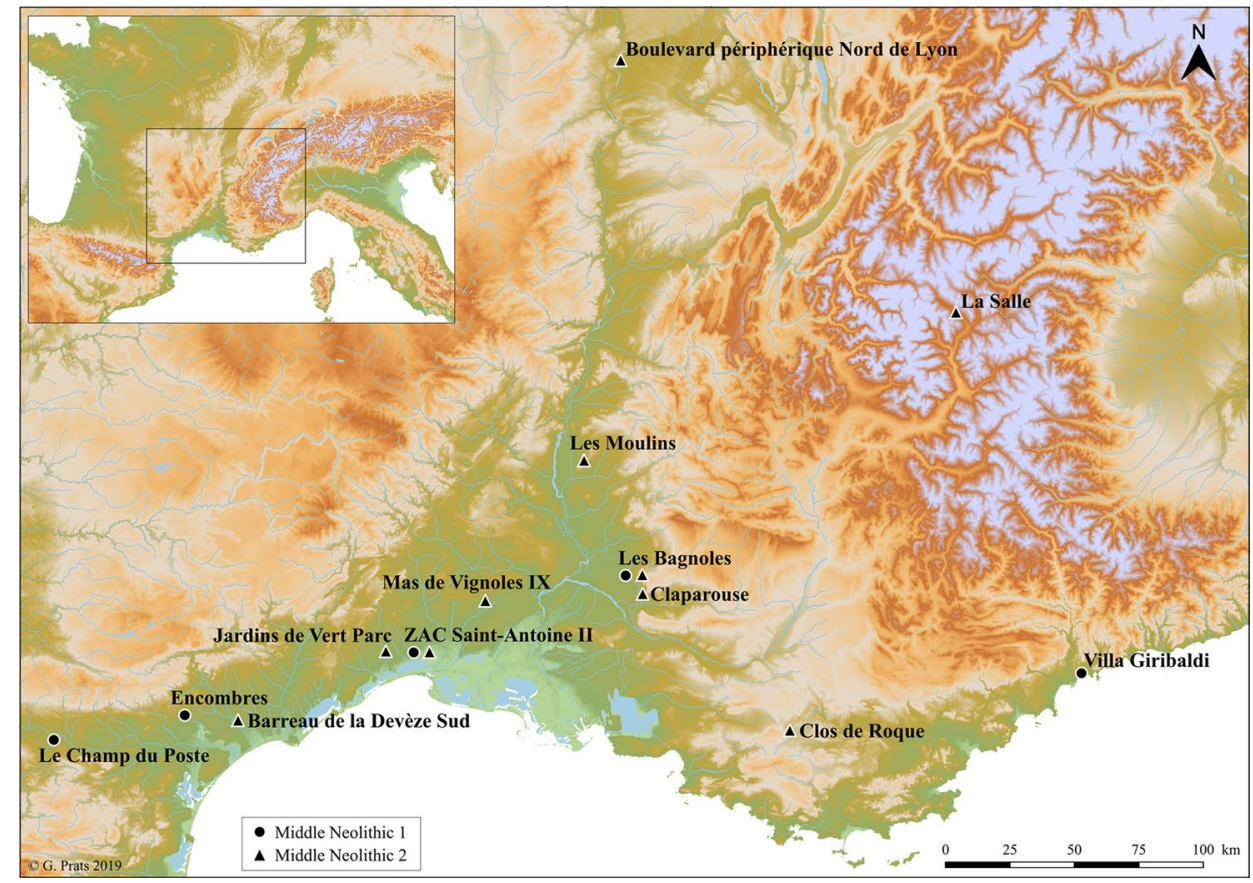


Table 1 Dates on seed and fruit remains from the wells at Les Bagnoles by ETH, Zürich

\begin{tabular}{|c|c|c|c|c|c|}
\hline Lab.code & Sample No & Taxon dated & Age (yrs вP) & cal вс $(2 \sigma)$ & References \\
\hline ETH-60868 & Str 250 P11 & Corylus avellana & $5,306 \pm 27$ & $4233-4048$ & Martínez-Grau et al. (2020) \\
\hline ETH-60867 & Str 250 P11 & Cerealia & $5,331 \pm 27$ & $4252-4051$ & Martínez-Grau et al. (2020) \\
\hline ETH-60870 & Str 250 P12 & Triticum sp. & $5,302 \pm 31$ & $4237-4042$ & Martínez-Grau et al. (2020) \\
\hline ETH-60871 & Str 250 below P13 & Cerealia & $5,323 \pm 31$ & $4252-4047$ & Martínez-Grau et al. (2020) \\
\hline ETH-88901 & Str 990 P70 & Triticum aestivum/durum/turgidum & $5,226 \pm 25$ & 4219-3969 & Martínez-Grau et al. (2020) \\
\hline ETH-88904 & Str 990 P25 & Triticum aestivum/durum/turgidum & $5,213 \pm 25$ & $4048-3968$ & Martínez-Grau et al. (2020) \\
\hline ETH-88902 & Str 994 P42 & Triticum monococcum & $5,027 \pm 26$ & $3943-3714$ & Martínez-Grau et al. (2020) \\
\hline ETH-96173 & Str 994 P45 & Triticum cf. monoсоссит & $5,096 \pm 28$ & $3966-3800$ & Unpublished \\
\hline ЕTH-88903* & Str 994 P44 & Triticum aestivum/durum/turgidum & $5,874 \pm 25$ & $4796-4693$ & Martínez-Grau et al. (2020) \\
\hline
\end{tabular}

Calibrated with OxCal v. 4.3.2 (Bronk Ramsey 2017) and IntCal13 atmospheric curve (Reimer et al. 2013)

*Interpreted as an error or a contamination

\section{Archaeobotanical analyses from Les Bagnoles}

The sediment samples were pre-treated with a water softener (Calgon) if samples were sieved in the field or by freezing and thawing (Vandorpe and Jacomet 2007). The latter method was used particularly for the waterlogged sediments. These were then sieved with the wash-over technique (Steiner et al. 2015) and the different fractions $(>4>1$ and $>0.35 \mathrm{~mm}$ ) were sorted under a stereo microscope. The $0.35 \mathrm{~mm}$ fractions were subsampled with the grid method (van der Veen and Fieller 1982) and ca. $10 \mathrm{ml}$ of residues were sorted. The resulting data were added to the ArboDat 2018 database (Kreuz and Schäfer 2002). Cereal identification criteria follow available literature (Jacomet 2006). This study uses the traditional nomenclature of Zohary et al. (2012) for crops. Only grains with embryo ends were counted (Jones 1990) and only nodes of free-threshing rachis remains or glume bases for glume wheats (Hillman et al. (1996). Cf. Pisum sativum (pea) pod fragments were counted if the fragments were larger than $12 \mathrm{~mm}^{2}$ (Fig. 2k) (description of these remains in Antolín and Schäfer 2020). Wild plants are not the object of study of this paper and are not included here, but the preliminary results were recently published (Antolín et al. 2020a, c; Jacomet 2020).

All in all, 65 samples from the three wells were analysed, adding up to more than $500 \mathrm{~L}$ of sediment. For most spits in the permanently waterlogged parts of each well, up to eight buckets ( $8 \mathrm{~L}$ each) of sediment were sieved, although only one or two of these were analysed. The analyses presented here are only a fraction of the total contents of the wells, and the screening of the remaining samples in the future may provide additional interesting finds such as extra cereal grains, charred seeds of pulses or large-seeded fruits. This paper therefore focuses on the general trends of the main crops. Each well is presented here as one feature since the samples were relatively homogeneous and no internal stratigraphy was observed in the waterlogged deposits (Table 1).

\section{Regional comparison of archaeobotanical data and silo pits}

Data from a total of 48 Middle Neolithic sites in southern France were included in the on-going AgriChange project database (Antolín et al. 2018). Of these sites, 27 are open-air sites, 15 caves, two shelters and three lakeshore settlements. All the sites yielded charred material but only three provided waterlogged plant remains, always from well contexts, Les Bagnoles, Clos de Roque and Mas de Vignoles IX. For this paper, we will focus on the open-air sites (Fig. 1) with pits, silos and wells as long as the data are available at a feature level, along with a clear chronology, either from radiocarbon dating or by pottery typology (Table 2 ). The data are organised according to the type of structure (well, pit/silo) and comparisons are made between each type of feature per phase and between the two phases of the Middle Neolithic period. The sites of Clos de Roque and Mas de Vignoles IX are both dated later than the MN2 period (ca. $3500 \mathrm{BC}$ ). They were, however, included in our analyses since there are only a few wells with waterlogged material, and they contributed significantly to the purposes of the paper. These sites are often integrated into syntheses about this period (van Willigen et al. 2014; Martin et al. 2016; Antolín et al. 2020b).

For incomplete grains, the total number of fragments of each taxon was divided by four and then added to the total of complete grain counts for the quantitative analyses. All barley identifications were grouped into one category, Hordeum distichon/vulgare, but it includes $H$. ssp. vulgare, H. ssp. nudum, Hordeum sp. and Hordeum remains (cfs). Grain counts were mostly used because chaff remains were only rarely found. Chaff was only used when there were no charred grains from sites with waterlogged material such as Clos de Roque, except Les Bagnoles.

Frequency per structure at a site level was used to produce bar plots that summarise the trends per phase, which 
a

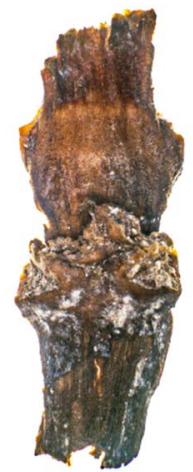

d

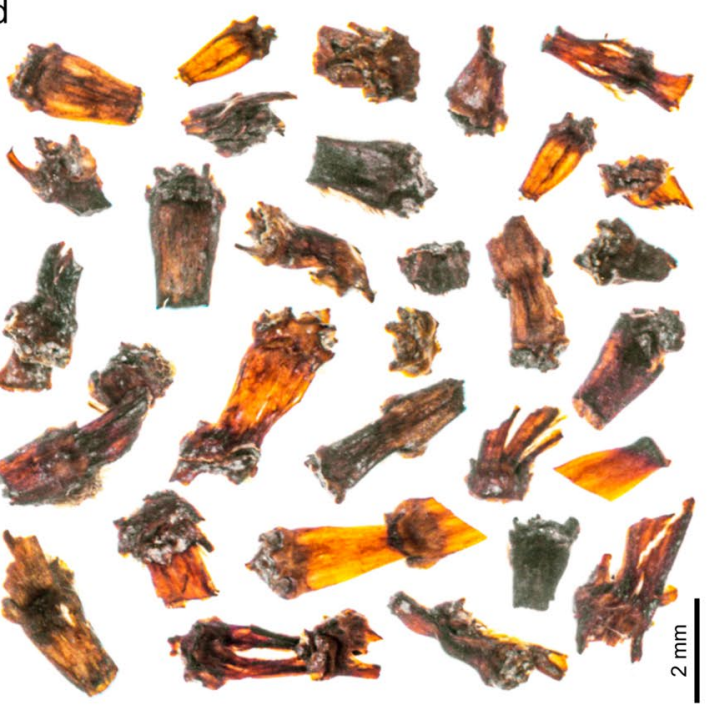

b

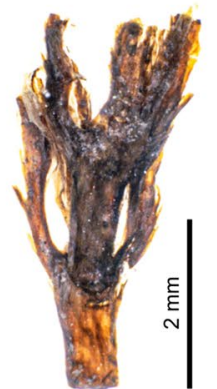

e
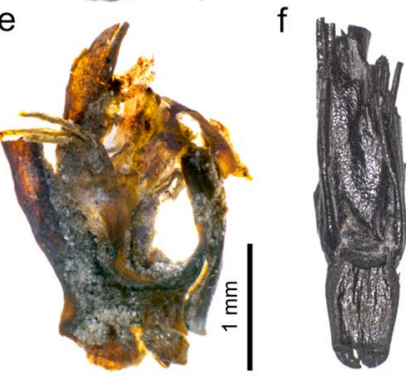

g

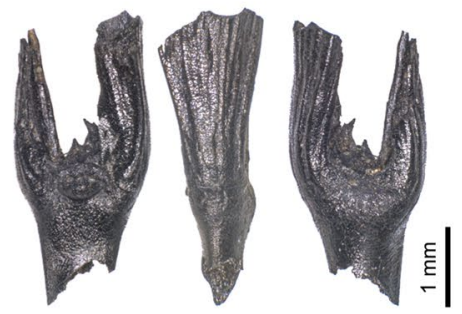

C h

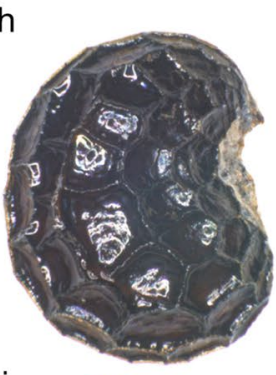

j

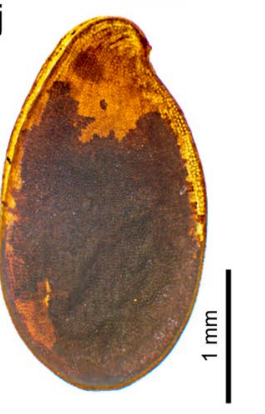

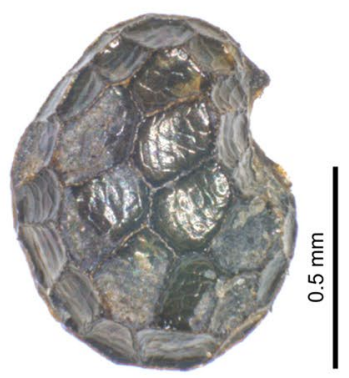

k

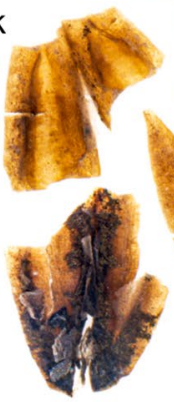

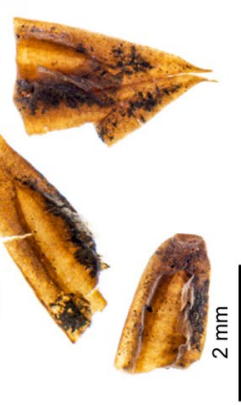

i
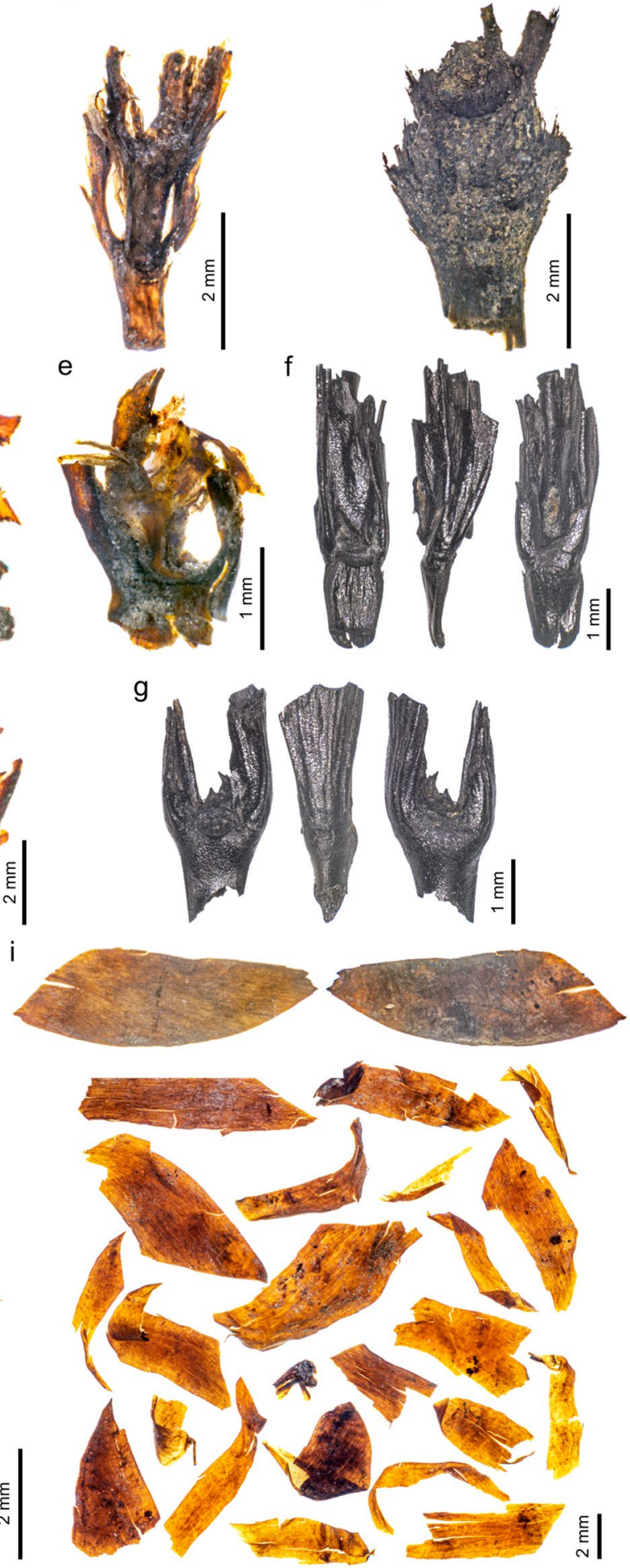


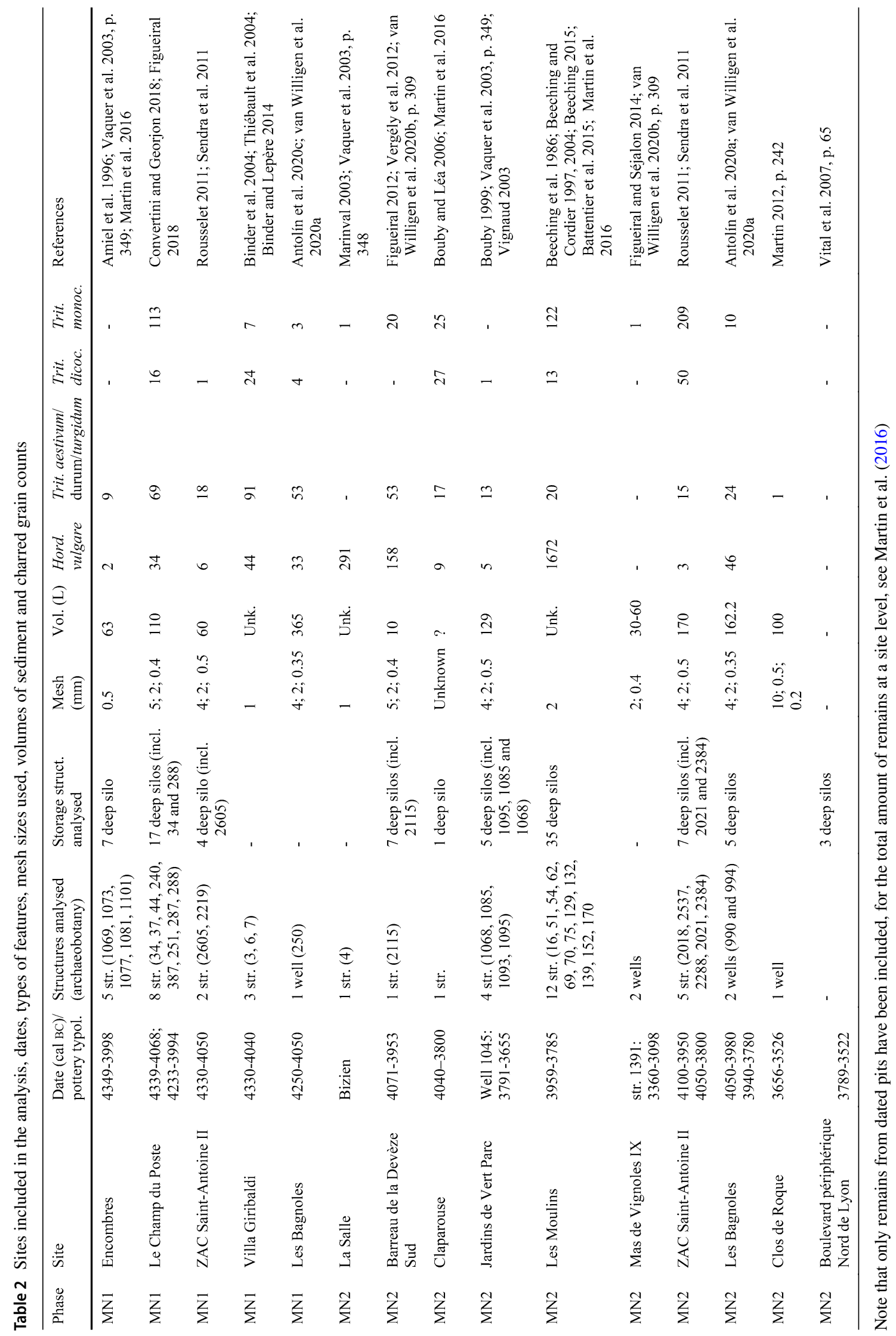


Table 3 Total results of the identification of cereal and fruit remains of cultivated plants from the three wells at Les Bagnoles

\begin{tabular}{|c|c|c|c|c|}
\hline Vol. (L) & & 379.1 & 60.6 & 84.2 \\
\hline Number of samples & & 39 & 13 & 13 \\
\hline Well & & 250 & 990 & 994 \\
\hline Chronological dates (cal BC) & & $4250-4050$ & $4050-3980$ & $3940-3780$ \\
\hline \multicolumn{5}{|l|}{ Cereals, charred } \\
\hline Hordeum distichon/vulgare & Grain & 33 & 36 & 10 \\
\hline Triticum aestivum/durum/turgidum & Grain & 53 & 13 & 11 \\
\hline Triticum dicoccum & Grain & 4 & & \\
\hline Triticum monococcum & Grain & 3 & & 10 \\
\hline Triticum monococcum/dicoccum & Grain & & 1 & \\
\hline Triticum sp. & Grain & 62 & 2 & 5 \\
\hline Cerealia indet. & Grain & 456 & 5 & 140 \\
\hline Hordeum distichon/vulgare & Rachis & 26 & 282 & 32 \\
\hline Triticum cf. aestivum type & Rachis & 1 & 6 & 7 \\
\hline Triticum cf. durum/turgidum type & Rachis & 34 & 175 & 38 \\
\hline Triticum aestivum/durum/turgidum & Rachis & 50 & 96 & 24 \\
\hline Triticum dicoccum & Glume base & 6 & 24 & 11 \\
\hline Triticum monococcum & Glume base & 2 & 22 & 64 \\
\hline Triticum monococcum/dicoccum & Glume base & 1 & 1 & \\
\hline Triticum sp, "new-type" & Glume base & & 21 & 2 \\
\hline Triticum sp. & Awn frag. & & & 3 \\
\hline Triticum sp. & Chaff & 9 & 13 & 13 \\
\hline Cerealia indet. & Ear base & 1 & 5 & 2 \\
\hline Cerealia indet. & Awn frag. & 24 & & 2 \\
\hline Cerealia indet. & Straw node & 22 & 10 & \\
\hline Cerealia indet. & Chaff & 21 & 112 & 129 \\
\hline \multicolumn{5}{|l|}{ Cereals, waterlogged } \\
\hline Cerealia indet. & Pericarp & 277 & 55 & 45 \\
\hline Hordeum distichon/vulgare & Rachis & 56 & 2601 & 10 \\
\hline Triticum cf. aestivum type & Rachis & & 4 & 16 \\
\hline Triticum cf. durum/turgidum type & Rachis & 71 & 3034 & 16 \\
\hline Triticum aestivum/durum/turgidum & Rachis & 55 & 586 & 6 \\
\hline Triticum dicoccum & Glume base & 4 & 735 & 15 \\
\hline Triticum monococcum & Glume base & 3 & 288 & 77 \\
\hline Triticum monococcum/dicoccum & Glume base & & 106 & 17 \\
\hline Triticum sp., "new-type" & Glume base & & 2 & \\
\hline Triticum sp. & Chaff & 3 & 50 & 9 \\
\hline Cerealia indet. & Ear base & & 16 & \\
\hline Cerealia indet. & Straw node & 10 & 2 & 2 \\
\hline Cerealia indet. & Chaff & 65 & 1,459 & 148 \\
\hline \multicolumn{5}{|l|}{ Pulses, charred } \\
\hline Lens culinaris & Seed & 2 & & \\
\hline Pisum sativum & Seed & 1 & & 1 \\
\hline Fabaceae (cf. Pisum sativum) & Pod fragment & & 1 & \\
\hline Vicia cf. faba & Seed & & 1 & \\
\hline \multicolumn{5}{|l|}{ Pulses, waterlogged } \\
\hline Pisum sativum & Seed & & 1 & \\
\hline Fabaceae (cf. Pisum sativum) & Pod fragment & 4 & 181 & 4 \\
\hline Fabaceae (cf. Pisum sativum) & Hilum & & 3 & \\
\hline Fabaceae (cf. Pisum sativum) & Calyx & & 5 & 1 \\
\hline \multicolumn{5}{|l|}{ Oil plants, charred } \\
\hline Linum usitatissimum & Capsule segment & & 2 & \\
\hline \multicolumn{5}{|l|}{ Oil plants, waterlogged } \\
\hline Linum usitatissimum & Seed & 1 & 36 & 4 \\
\hline Linum usitatissimum & Capsule segment & 1 & 231 & 4 \\
\hline Papaver somniferum ssp. somniferum/setigerum & Seed & 292 & 54 & 15 \\
\hline
\end{tabular}


represents most accurately the recurrence of the use of a crop taxon within each particular phase at the sites (Popper 1988).

In order to see if these recurrences had a direct expression in the number of grains per crop found per site, we calculated proportions of each crop type for all features with at least 30 identified cereal grains. For the first phase MN1, material from six features and for MN2, five features were available. These results were again drawn as bar plots with the standard deviation shown.

\section{Analysis of storage capacity}

Due to the lack of the original ground surface at most openair sites excavated in our study region, storage features can only be analysed as isolated contexts and not in relation to dwellings or similar features. We cannot be sure if a silo could be related to only one household and that is why we are not interpreting isolated values, but observing the general trend for each of the two chronological phases, as in Prats et al. (2020).

Underground storage features from the analysed sites were classified typologically and their capacity was calculated (for the methodology, see Gilabert 2009; Prats 2017; Prats et al. 2020), to correlate it with any potential changes in the crop assemblage. The resulting volume values are inevitably an underestimate of their real storage capacity (Bogaard et al. 2009).

We initially considered a total of 91 underground features with a clear chronology, with a $<3.5$ top diameter/ depth index (D-D index) and with a depth of more than $35 \mathrm{~cm}$. Most of the Middle Neolithic pits are bell-shaped (ESM Fig. 3), as observed in Catalonia (Prats 2017), so this will not be further discussed here. From MN1, 28 features from three sites, Encombres, Le Champ du Post and ZAC Saint-Antoine II were analysed with an average depth of $55 \mathrm{~cm}$ and average D-D index of 2.5 (Fig. 1). From MN2, 63 structures from seven sites, Barreau de la Devèze Sud, Boulevard périphérique Nord de Lyon, Claparouse, Jardins de Vert Parc, Les Bagnoles, Les Moulins and ZAC SaintAntoine II, were analysed, with an average depth of $72 \mathrm{~cm}$, average D-D index of 1.5 and with better preservation than the MN1 features.

\section{Results}

\section{General results from Les Bagnoles}

Overall, 844 remains of charred cereal grains, 1,291 charred and almost 9,500 waterlogged chaff remains were found (Table 3, photos of a selection of remains in Fig. 2). Oil plants and pulses were mostly identified from waterlogged remains (837 waterlogged remains, eight charred). Up to six cereal taxa were identified, barley (identified as Hordeum distichon/vulgare, but mostly belonging to six-rowed naked barley), with the presence of the two-rowed type as shown in Fig. 2b, c. Naked wheat included both types of chaff remains, hexaploid T. aestivum-type and the tetraploid durum/turgidum-type, the latter being overwhelmingly dominant. Glume wheats were found, such as Triticum dicoccum (emmer), T. monococcum (einkorn) and the new type glume wheat (Triticum sp. new type), which are shown in Fig. 2. Free threshing cereals (barley and naked wheat) are in general better represented than glume wheats, in a proportion of 8:1 for grains and 5:1 for chaff remains, both charred and waterlogged. Fragments of the ear base were found in all wells, as well as straw nodes both charred and waterlogged. Waterlogged cereal pericarp and testa fragments, mostly not identifiable to species level, were also recovered. Three species of pulses were found, Lens culinaris (lentil), Pisum sativum (pea) and Vicia cf. faba (broad bean), but the number of finds was very low. Only cf. Pisum sativum (pea) pod fragments were found in significant numbers. Two oil plants were almost exclusively represented by waterlogged remains of Linum usitatissimum (flax) and Papaver somniferum ssp. somniferum/setigerum (possible opium poppy) (Fig. 2h-j).

\section{Well 250 (ca. 4250-4050 cal Bc)}

Naked wheat grains are dominant in this well, followed by barley, while glume wheat grains are very rare (Fig. 3a). Among the oil plants and pulses, opium poppy is the best represented, while this is the only well from which lentil has been found at Les Bagnoles.

\section{Well 990 (4050-3980 cal BC)}

Hordeum (barley) is clearly dominant in this feature, both in grain and chaff remains, followed by Triticum (naked wheat). Charred chaff remains of barley are as well represented as naked wheat, while glume wheats reach ca. $10 \%$ of the total remains (Fig. 3b). Uncharred chaff remains show a more explicit dominance of barley, followed by naked wheat and a more important representation of glume wheats $(15 \%)$. The new type glume wheat was also found in this well. Pea was the dominant pulse in this well, although it also yielded the only find of Vicia faba (broad bean) from the site. Both capsule and seed remains of Linum (flax) were found in this well, also more than 50 seeds of opium poppy.

\section{Well 994 (3940-3780 cal BC)}

The most recent well shows a clearly different crop spectrum, with an equal representation of all cereal groups. In 

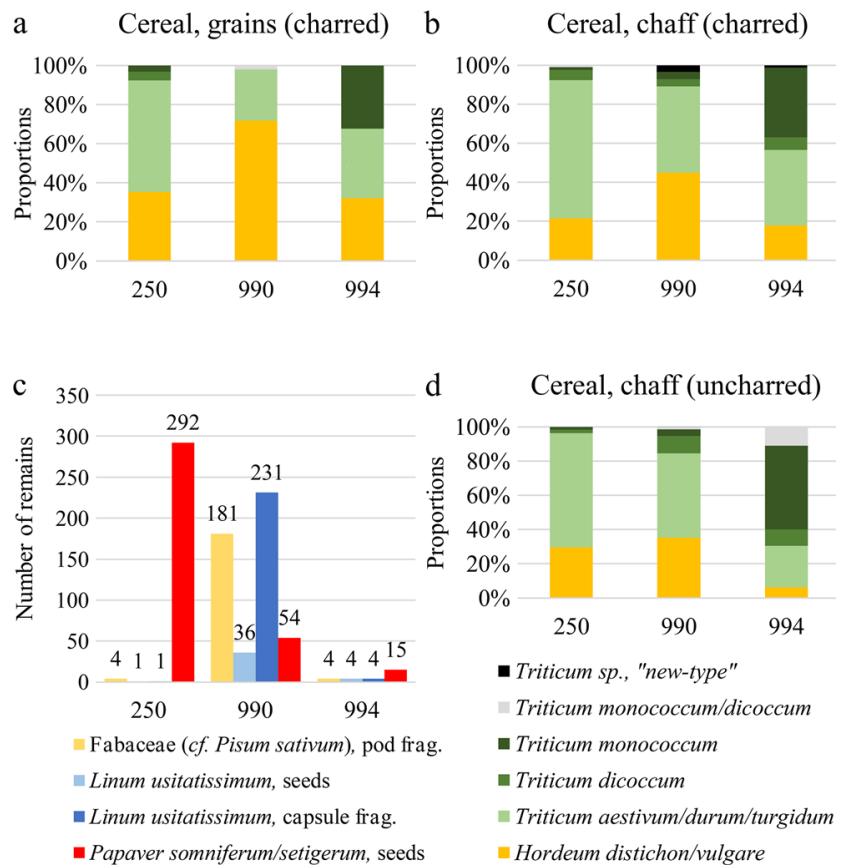

Fig. 3 Proportions of the most important cereal taxa from Les Bagnoles according to a charred grains; $\mathbf{b}$ cereal charred chaff remains; c number of remains found per well of the main pulses and oil crops (only waterlogged remains); $\mathbf{d}$ uncharred (waterlogged) chaff remains

fact, chaff remains of glume wheats are dominant both in the charred and the uncharred record (Fig. 3d). Naked wheat is particularly badly represented among the chaff remains. Oil plants and pulses were recorded in small amounts (Table 3 ).

\section{Discussion}

\section{The crops from the wells at Les Bagnoles in the context of the Early and Middle Neolithic of southern France and adjacent regions}

Thousands of uncharred waterlogged chaff remains from naked and glume wheat and also from barley, along with abundant finds of oil plants and pulses, were found from the wells at Les Bagnoles. Neolithic sites with waterlogged preservation are rare in Mediterranean Europe, and dry sites often reveal a limited insight into plant economy due to taphonomic factors. This makes the findings from Les Bagnoles unique and provides a new insight into crop diversity during the Middle Neolithic period in southeastern France.

The infillings of the wells represent accumulations of refuse during the immediate period after the last use of the wells for their original purpose. Besides plant finds, large amounts of animal remains (mostly bones, but also dung of vertebrates and large amounts of invertebrates, mainly insects), pottery, grinding stones, etc. were recovered from these features, suggesting their closeness to the living area (for a discussion of the possible origin of well infillings see Jacomet 2020 and the literature cited there). Therefore, the contents of the wells inform us about domestic economic practices as may do other negative features such as pits and silo pits, which were filled with deposits of secondary refuse (Kreuz 1990; Schiffer 1991; LaMotta and Schiffer 2002; Fuller et al. 2014), with the added benefit of having waterlogged plant remains preserved. Such waterlogged features offer excellent preservation conditions, which allow not only the preservation of a considerable number of charred grains and abundant chaff remains, but particularly also uncharred waterlogged chaff.

Barley is one of the best represented crops at the site. Chaff remains suggest the presence of mostly six-rowed naked barley in all the Les Bagnoles wells, but two-rowed barley was also present. The presence of both types of barley during the Middle Neolithic in the area had not yet been noticed before, mainly due to the scarcity of chaff remains in the archaeobotanical record. Barley seems to have spread in the northwestern Mediterranean area since the Early Neolithic period in the first Impressa culture sites (ca. 5850-5650 cal BC) in southern France (Bouby et al. 2020a). Ear and rachis fragments of two-rowed barley (unclear if hulled or naked) were recorded from La Draga in Banyoles, Spain, belonging to the Cardial culture (ca. 5400-5000 cal BC) (Antolín et al. 2014, 2015). However, only a few barley rachis remains have been recovered from the Middle Neolithic sites of the northwestern Mediterranean, and these were not identified to variety level (Antolín 2016), although they seem to be of the six-rowed type, as suggested in the recent study of the site of Auvelles (Castelló de Farfanya, Catalonia) (Antolín in press).

Naked wheat also spread quickly across the western Mediterranean since the early Neolithic, mostly the tetraploid type (Triticum durum/turgidum), found at sites such as La Marmotta (Lago di Bracciano, Italy) (Rottoli 1993) and La Draga (Llac de Banyoles, Spain) (Antolín et al. 2014). Possible rachis fragments of the hexaploid type were reported from La Draga, just like the ones found from Les Bagnoles, mixed with the dominant tetraploid ones. The presence of both types of naked wheat together has long been known from the circum-Alpine Neolithic pile dwellings (Schlumbaum et al. (1998), although the tetraploid type was also strongly dominant there. Thus, we can confirm that tetraploid naked wheat was present in southern France and probably dominant over other naked wheats during the Middle Neolithic, which was not known until now due to the scarcity of chaff remains at previously investigated sites, as reported by other authors (Martin et al. 2016). 
The results of Les Bagnoles indicate a significant increase of einkorn in the most recent well, dated to ca. 3950-3750 cal вс (MN2). Earlier results have shown that during the early Neolithic (5th millennium BC) these glume wheats had considerable importance in the area investigated, but then during MN1 they became rare, before they regained importance during MN2 (Bouby et al. 2020a; de Vareilles et al. 2020). This increase coincides with general observations based on grain counts from sites in southern France (Martin et al. 2016; Antolín et al. 2020b), which suggest a revived focus on glume wheats. In order to avoid taphonomic biases, we will test this hypothesis using a contextual approach, by using only negative features such as wells and pits in the following section (as in Jesus et al. 2020).

Until now, the new type of glume wheat had only been found at a Middle Bronze Age site (ca. 1500 BC) in southern France (Toulemonde et al. 2015), while Neolithic finds seemed to be restricted to the Linearbandkeramik (LBK) area. The recent finds of this taxon in northern Italy (Rottoli and Castiglioni 2009) and other Mediterranean sites such as La Draga and Can Sadurní in Catalonia (Antolín et al. 2015; Antolín 2016) show that it was present in the area since the 6th millennium $\mathrm{BC}$, but probably not as a crop on its own. This is presumably also the case at Les Bagnoles, judging from the available evidence.

The results from Les Bagnoles are even more relevant regarding pulses and oil plants. Pulses have already been found from other sites, particularly Lathyrus cicera/sativus (pea, grass pea) and Vicia sativa (common vetch), but the numerous waterlogged probable pea pod fragments found at Les Bagnoles show that their importance is clearly underestimated in the charred record. In addition to this, one seed of Vicia faba (broad bean) was also recovered, which had not been identified to date in this region (Martin et al. 2016). The abundant remains of Linum (flax) seeds and capsule segments and Papaver somniferum (opium poppy) also suggest that their importance in the economy was greater than originally considered, because they are rarely preserved at dry sites (Jacomet 2013).

\section{Importance of crops at Les Bagnoles compared to other Middle Neolithic wells and pits in southern France}

In order to discuss the representativeness of the data on crop changes obtained from the wells at Les Bagnoles in the context of southern France as a whole, we compared first the results from other wells in the region and then from other negative features, as taphonomically comparable deposits.

Sites with waterlogged deposits are extremely rare in southern France. As already mentioned, there are only the wells at Mas de Vignoles (Nîmes) (Figueiral and Séjalon 2014) and Clos de Roque (Saint-Maximin-la-Ste-Baume, Dépt. Var) (Martin 2012). However, little is known about the methodologies used for sampling and processing the waterlogged plant remains from these sites. Only the well of Clos de Roque yielded waterlogged plant remains in high numbers. Unfortunately, the sieved fractions were dried, which probably destroyed all fragile plant remains such as chaff fragments (for a discussion of this topic see Tolar et al. 2010). Both wells also provided a very small amount of charred cereal remains, which renders them irrelevant for the characterization of cereal agriculture in the Neolithic period (Table 4). The scarcity of charred material from Mas de Vignoles led the authors to suggest that food preparation was not taking place near the wells and that the lack of material indicates that these structures were on the periphery of the living area (Figueiral and Séjalon 2014, p 33). Conversely, Papaver seeds (presumably uncharred) were found from both wells, confirming the importance of poppy and its consistent underrepresentation at dry sites due to preservation and recovery issues. Pulses were not reported from the wells at Clos de Roque and Mas de Vignoles IX.

The data from Les Bagnoles, with abundant waterlogged remains of chaff and presence of pulses and oil plants, have more in common with the lakeshore sites of different parts of Europe, such as the Jura region in France, in Switzerland and in southern Germany (for example, Maier 2001; Jacomet 2007, 2014). This dissimilarity with other wells in southern France may be due to methodological reasons and it probably suggests that if more wells had been properly excavated and sampled, supraregional comparisons between these areas would be possible.

The charred archaeobotanical record from Les Bagnoles was compared on a regional level with southern France, calculating both the ubiquity (presence) and the proportion of remains of each crop per site. The sites are grouped chronologically into MN1 or MN2, as shown in Table 2.

The calculation of ubiquities at a feature level resulted in the same trend as observed from Les Bagnoles, with a decrease in naked wheat (and emmer), similar importance of barley and a significant increase in einkorn (Fig. 4a). This suggests that the observed trend is representative at the level of the domestic economy, since ubiquity values best reflect the repetition of activities in the past. In order to confirm this, we calculated the average proportions of the same crops at a structure level, only using features with 30 or more crop remains, now including Les Bagnoles to make the dataset more solid (Fig. 4b). The decrease in naked wheat and the increase in einkorn are also clearly visible using this approach, and it therefore confirms the previously observed trend. This is in slight disagreement with the increase of emmer proposed by Martin et al. (2016), which could be due to our different approach and focus on open-air sites. 
Table 4 Cultivated plant list from the archaeobotanical analyses of the Neolithic wells studied in southern France (for cereals only grains are shown)

\begin{tabular}{|c|c|c|c|c|c|c|}
\hline \multirow{3}{*}{$\begin{array}{l}\text { Site } \\
\text { Age cal BC } \\
\text { Well }\end{array}$} & \multicolumn{3}{|c|}{ Les Bagnoles } & \multirow{3}{*}{$\begin{array}{l}\text { Clos de Roque* } \\
3650-3350 \\
\text { ST2096 }\end{array}$} & \multirow{2}{*}{\multicolumn{2}{|c|}{$\frac{\text { Mas de Vignoles IX** }}{\text { Middle Neolithic (Chasséen) }}$}} \\
\hline & \multirow{2}{*}{$\begin{array}{l}4200-4050 \\
250\end{array}$} & \multirow{2}{*}{$\begin{array}{l}4030-3980 \\
990\end{array}$} & \multirow{2}{*}{$\begin{array}{l}3980-3880 \\
994\end{array}$} & & & \\
\hline & & & & & 1157 & 1051 \\
\hline Stratigraphic unit & Several & Several & Several & 16 & 1719 & 1724 \\
\hline Volume (1) & 379.1 & 60.6 & 84.2 & 100 & $20-30$ & $20-30$ \\
\hline \multicolumn{7}{|l|}{ Cereals (grains, charred) } \\
\hline Hordeum vulgare & 33 & 36 & 10 & & & \\
\hline Triticum dicoccum & 4 & & & & & \\
\hline T. monococcum & 3 & & 10 & & & 1 \\
\hline T. monococcum/dicoccum & & 1 & & 1 & & \\
\hline T. aestivum /durum/turgidum & 53 & 13 & 11 & 1 & & \\
\hline \multicolumn{7}{|l|}{ Pulses (seeds, charred) } \\
\hline Pisum sativum & & 1 & & & & \\
\hline \multicolumn{7}{|l|}{ Oil plants (seeds, uncharred) } \\
\hline $\begin{array}{l}\text { Papaver somniferum ssp. } \\
\text { somniferum/setigerum }\end{array}$ & 292 & 54 & 15 & 593 & 5 & \\
\hline Linum usitatissimum & 1 & 36 & 4 & & & \\
\hline
\end{tabular}

\section{Possible reasons for the change in crop choice at the beginning of the 4th millennium $B C$}

The increase in the presence of glume wheats has been discussed already. Martin et al. (2016) propose some possible causes, such as cultural contacts, expansion of farming on to poorer soils, environmental changes or techno-economic changes.

Cultural contacts are indicated by finds which show the exchange of materials such as pottery, raw materials and stone objects. Examples of these are found from throughout the Neolithic period and normally associated with rivers as exchange routes such as the Rhine and also the Mediterranean coastline (Denaire et al. 2011). According to evidence from MN2 burials there are clear signs of exchanges between northern Italy, Catalonia and Switzerland; differences in the funerary practices in southern France also show distinct regional groups within the late Neolithic "classic Chassey" culture such as the Rhodanien Chassey and the Bize group (Vaquer 2014). There is little evidence of house plans in southeastern France, however the few which are available show cultural influences from Switzerland (Cortaillod culture) and from northern Italy (Chassey-Lagozza culture) (Saintot et al. 2009, p. 120; Giligny and Sénépart 2018, pp. 35-42). The presence of Chassey pottery and artefacts in the Sepulcres de Fossa communities in Catalonia demonstrate exchange between these two groups (Mestres and Tarrús 2016), as well the presence of pearls made of variscite (a phosphatic mineral) from Gavà (Spain) in MN2 burials in southeastern France (Vaquer 2014, p. 2). The archaeobotanical record from the Middle Neolithic in
Catalonia is dominated by naked barley and naked wheat (Antolín in press; Antolín et al. 2015, 2018), so it is unlikely that cultural contacts with this region favoured the choice of glume wheats over free-threshing cereals. Unfortunately, the archaeobotanical record in northern Italy is poorly known, and we cannot be sure if glume wheats could have arrived from that region (Rottoli and Castiglioni 2009). Current analyses on the lakeshore site of Isolino di Varese suggest that this possibility exists (Antolín, unpublished). Influences from the western Balkans could possibly explain the cultural factors affecting crop choice in northern Italy, considering the state of research for this period (Reed 2016), but much more research is needed on northern Italy to show that this was the case. In such a hypothetical scenario, the contacts between northern Italy and southern France could also have favoured the increased presence of glume wheats in the latter region, but this is currently a matter of pure speculation. In fact, glume wheats were always present to some degree in the region, so external influences might not be the only reason for an increase in these crops. This could also be due to changes in preferences and uses of the crop by-products, for instance. As indicated by Bouby et al. (2020b), einkorn was still an important crop in southern France during the Late Neolithic (3500-2200 BC), with an apparent lack of correlation with climatic events, which would suggest that the choice could have been just a matter of a greater interest in this crop. Ethnographic studies show that einkorn is used nowadays by people with less income (Peña-Chocarro et al. 2009, p. 109), despite its lower productivity and higher workload requirements, such as for dehusking, but this could have been perceived in a different way in the past. The 
a

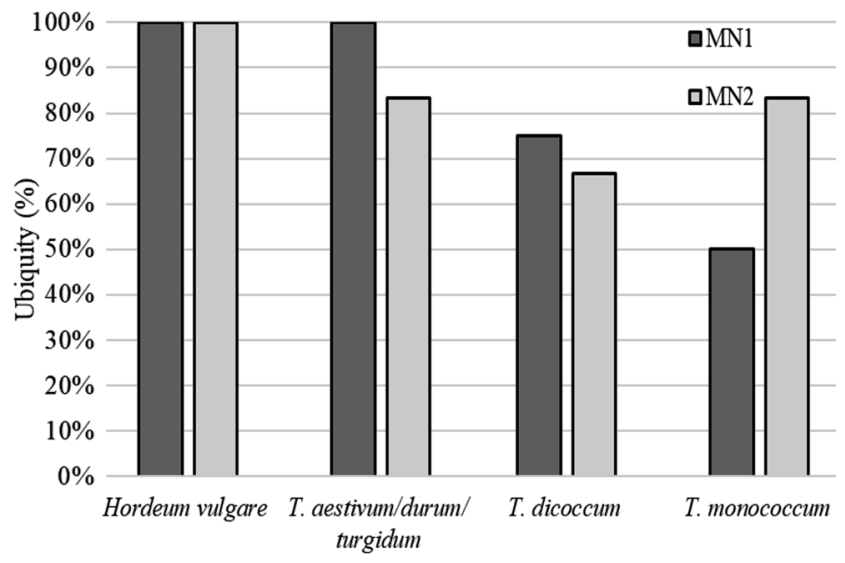

b

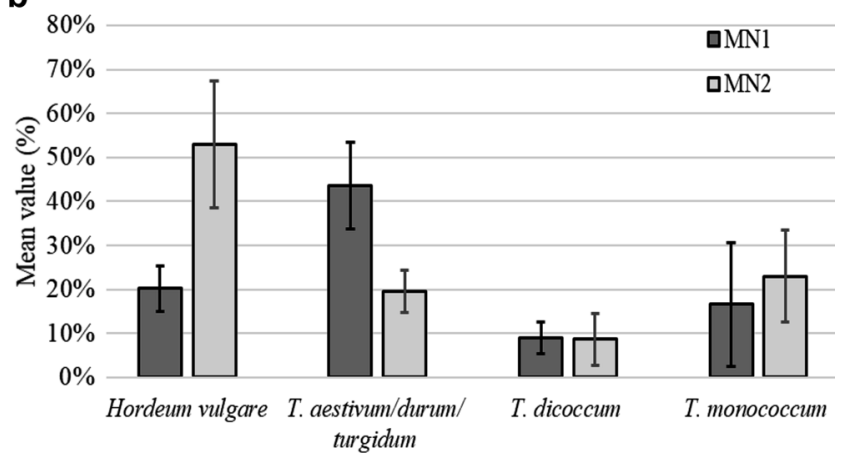

Fig. 4 Comparison of ubiquities and proportions at a context level between pits/silos from open-air sites in southern France grouped into MN1 and MN2 phases. a ubiquity of each crop at a feature level (silo/pit) per site, wells excluded (MN1, 5 sites; MN2, 6 sites, further details in Table 4); $\mathbf{b}$ average value and standard deviation obtained from the proportions calculated for each crop at a feature level, including the wells of Les Bagnoles. (MN1, 3 sites and 6 structures; MN2, 5 sites and 7 structures)

villages where einkorn is still grown nowadays are intimately associated with traditional uses of the crop by-products such as the use of einkorn straw for thatching, and for making hats and other things (Peña-Chocarro et al. 2009, p. 109; Hajnalová and Dreslerová 2010, p. 171). This might suggest that during MN2 there could have been a change of preference to a richer grain in terms of taste and nutrients, which is more resistant to fungi and to harsh weather but also had possible uses of its straw for other activities. This preference could have been sustained in some areas of southern France until the Late Neolithic period (Bouby et al. 2020b).

Climatic influence could also have determined the type of wheat which was grown. Glume wheats have several advantages compared to free-threshing wheat. It is well known that their storage in spikelet form protects them from insect attack both in the field and in storage (Jones et al. (1986). Glume wheats are known for surviving harsh conditions and poor soils, yet still providing good yields (Laghetti et al. 2009, p. 4), while under colder weather conditions einkorn is the most durable (Laghetti et al. 2009, p. 6). Emmer is also known to resist fungal diseases (Laghetti et al. 2009, p. 4). A recent palaeoclimatic model suggests that there were lower mean annual temperatures and particularly lower annual rainfall after $4000 \mathrm{BC}$ in the area around Les Bagnoles (Contreras et al. 2018, Fig. 2). While durum wheat would have tolerated drier climatic conditions, a colder climate in combination with lower rainfall could have been a reason for a reduction in productivity of naked wheat (Pala et al. (1996).

In order to test a possible influence of climate on annual crop productivity, we decided to use underground storage capacity as an indicator. Given that glume wheats are stored as spikelets (see above), an increase in storage capacity would be expected for these in MN2, if productivity and storage practices stayed constant. As mentioned above, 28 features from three MN1 sites and 63 structures from seven MN2 sites were taken into consideration (ESM Table 1).

The comparison between the volumetric means (MN1, $866 \mathrm{~L} ; \mathrm{MN} 2,797 \mathrm{~L})$ and the medians (MN1, $855 \mathrm{~L}$; MN2, $662 \mathrm{~L}$ ) between MN1 and MN2 unexpectedly reveals a small volume decrease in MN2 (Fig. 5). Actually, neither mean value can be considered significantly different according to the $\mathrm{T}$ test. As explained in the introduction, this contradicts our hypothesis that growing more glume wheats would lead to larger mean storage capacity values. We exclude a taphonomic bias because, as shown in the results, the MN2 silo pits are better preserved. It is also an unexpected trend compared with previous diachronic evaluations in nearby regions such as Catalonia (Prats et al. 2020). This result may be due to various reasons: 1 , an overall lower productivity during MN2; , a more diverse storage system during MN2, including aboveground structures or large jars, which could only be further investigated archaeologically; 3 , a continuity of storage pit shape and capacity irrespective of productivity; or 4, a biased result influenced by our choice of sites. Although the state of research is still at an early stage, we interpret the lack of significant increase in storage values in MN2, coupled with the decrease of naked wheat in the record, as signs of lower productivity of naked wheat grown. It could be due to less favourable climatic conditions, as suggested above, that farmers tried to compensate for by growing more einkorn, already present in previous phases but in small amounts, thus increasing its ubiquity and absolute numbers in the MN2 record.

For the moment, it is not clear if one or all of these hypotheses may play a role in explaining the decrease of naked wheat and increase of einkorn in MN2. Future investigations should look into further aspects such as crop pests or crop or artefact exchange as well as other indicators of cultural influences (such as new house plans, funerary practices or regional pottery styles) between Switzerland, southeastern France, northern Italy, the western Balkans and Catalonia in order to give a better indication of cultural contacts among them. 


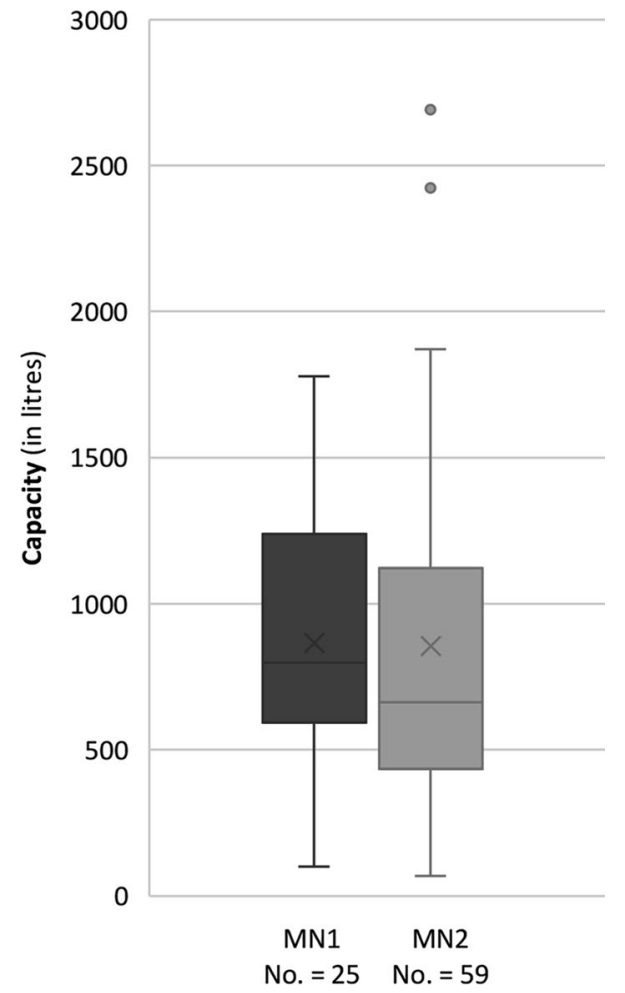

Fig. 5 Box plots summarizing the minimum and maximum volumes in $\mathrm{L}$ of the preserved parts of the silos, as well as the medians and means ( $\times$ ) for MN1 (3 sites) and MN2 phases (7 sites)

\section{Conclusion}

This paper discusses the archaeobotanical results from three Middle Neolithic wells at Les Bagnoles in southeastern France and compares them to other similar structures at sites of the two phases of the Middle Neolithic period. The results from Les Bagnoles provide an unusually large amount of data that allow new detailed insights into agriculture in Middle Neolithic France. The large quantity of plant remains found at this site, in comparison to other investigated wells, shows how essential it is to apply the appropriate sampling and sample processing methodology to such waterlogged sediments. Uncharred cereal chaff remains are among the first types of finds to be damaged by inappropriate sieving and handling of the sieving residues. At the same time, charred material is also better preserved in such waterlogged contexts and it was retrieved in significantly greater amounts from Les Bagnoles compared to other contemporary sites. A continuation and improvement in systematic sampling and sediment processing techniques are therefore necessary to achieve the desired quality and quantity of data on Neolithic farming practices in the region.
The regional comparison of the available archaeobotanical data shows some further gaps in research, such as absence of full context-level publications and clear dating of archaeological features and/or archaeobotanical material. The review in this paper is solidly based on a selected choice of reliably dated features and thus it obtained novel results. Our results partly corroborate existing chronological overviews in that there is a slight decrease in the presence of naked wheat and increase of glume wheats. The difference is that in our study, einkorn is more predominant in refuse deposits from open-air sites dated after $4000 \mathrm{cal} \mathrm{BC}$. These results indicate that the increase in interest towards this crop happened before the Late Neolithic, as suspected until recently. The comparison of the archaeobotanical results with the underground storage capacity values revealed unexpected patterns that suggest increased instability in crop productivity which probably affected naked wheat crops, coupled with the increased presence of glume wheats, which from then onwards became more important in the record. This integrated approach opens new ways of dealing with factors affecting crop choice in prehistory. This comparison shows that by looking at the same data but examining it according to the type of context, such as silos, new perspectives appear, as well as new questions. Further insights may be gained in the future by integrating other proxies such as stable isotope analysis of grains and evidence for crop pests in the region, which are currently in progress within our AgriChange project.

Acknowledgements The authors would like to thank Laurent Bouby, Lucie Martin, Isabel Figueiral and Samuel van Willigen for sharing site reports and their own personal raw data and Ruth Sahli and Raül Soteras for sieving the samples. The comments of three anonymous reviewers and those of James Greig (copy editor) also contributed to the improvement of the paper. The Schweizerischer Nationalfonds zur Förderung der wissenschaftlichen Forschung (Swiss National Science Foundation) has funded this research as part of a SNSF professorship for F. Antolín, Grant Number PP00P1_170515.

Funding Open access funding provided by University of Basel.

Open Access This article is licensed under a Creative Commons Attribution 4.0 International License, which permits use, sharing, adaptation, distribution and reproduction in any medium or format, as long as you give appropriate credit to the original author(s) and the source, provide a link to the Creative Commons licence, and indicate if changes were made. The images or other third party material in this article are included in the article's Creative Commons licence, unless indicated otherwise in a credit line to the material. If material is not included in the article's Creative Commons licence and your intended use is not permitted by statutory regulation or exceeds the permitted use, you will need to obtain permission directly from the copyright holder. To view a copy of this licence, visit http://creativecommons.org/licenses/by/4.0/. 


\section{References}

Alonso N, Antolín F, López D et al (2013) The effect of dehusking on cereals: experimentation for archaeobotanical comparison. In: Anderson PC, Cheval C, Durand A (eds) Regards croisés sur les outils liés au travail des végétaux: actes des rencontres 23-25 octobre 2012: XXXIII rencontres Internationales d'Archéologie et d'Histoire d'Antibes. An interdisciplinary focus on plant-working tools. Editions APDCA, Antibes, pp 155-168

Amiel C, Carrère I, Mahieu É (1996) Premières données sur l'habitat chasséen d'Encombres, Quarante. Document final d'opération de diagnostic, SRA Languedoc-Roussillon, AFAN ..., Montpellier/ Aix-en-Provence/Nîmes

Antolín F (2016) Local, intensive and diverse? Early farmers and plant economy in the North-East of the Iberian Peninsula (5500-2300 cal BC). Barkhuis, Eelde

Antolín F (in press) Estudi paleocarpològic (llavors i fruits) del jaciment d'Auvelles i l'agricultura del Neolític mitjà a la plana occidental catalana. In: Mangado X, Sánchez-de-la-Torre M (eds) L'assentament arqueològic de les Auvelles (Castelló de Farfanya, La Noguera) en el context de la mineria del sílex a la Prehistòria. Monografies del SERP, Universitat de Barcelona

Antolín F, Schäfer M (2020) Insect pests of pulse crops and their management in Neolithic Europe. Environ Archaeol. https://doi. org/10.1080/14614103.2020.1713602

Antolín F, Buxó R, Jacomet S et al (2014) An integrated perspective on farming in the early Neolithic lakeshore site of La Draga (Banyoles, Spain). Environ Archaeol 19:241-255. https://doi. org/10.1179/1749631414Y.0000000027

Antolín F, Delefosse C, Errera M et al (2020a) Les structures attribuables au Néolithique moyen de type La Roberte (fin du Ve millénaire-début de l'Ive millénaire avant notre ère). In: van Willigen S, Bailly M, Röder B, et al. (eds) Les Bagnoles à L'Isle-sur-laSorgue (Vaucluse) - le Néolithique moyen et les occupations postérieures (âge du Bronze, âge du Fer et Antiquité). Presses Universitaires de Provence, Aix-en-Provence, pp 229-280

Antolín F, Häberle S, Jesus A et al (2018) The AgriChange project: an integrated on-site approach to agricultural and land-use change during the Neolithic in Western Europe. Past Glob Chang Mag 26:26-27. https://doi.org/10.22498/pages.26.1.26

Antolín F, Jacomet S, Buxó R (2015) The hard knock life. Archaeobotanical data on farming practices during the Neolithic (54002300 cal BC) in the NE of the Iberian Peninsula. J Archaeol Sci 61:90-104. https://doi.org/10.1016/j.jas.2015.05.007

Antolín F, Jesus A, Follmann F, Jacomet S (2020b) Économie et alimentation. In: van Willigen S, Bailly M, Röder B, et al. (eds) Les Bagnoles à L'Isle-sur-la-Sorgue (Vaucluse)—le Néolithique moyen et les occupations postérieures (âge du Bronze, âge du Fer et Antiquité). Presses Universitaires de Provence, Aix-enProvence, pp 316-329

Antolín F, Schmitt A, Bader M et al (2020c) Les structures attribuables au Néolithique moyen de type Chassey (dernier tiers du Ve millénaire avant notre ère). In: van Willigen S, Bailly M, Röder B, et al. (eds) Les Bagnoles à L'Isle-sur-la-Sorgue (Vaucluse)—le Néolithique moyen et les occupations postérieures (âge du Bronze, âge du Fer et Antiquité). Presses Universitaires de Provence, Aix-en-Provence, pp 117-228

Battentier J, Thiébault S, Binder D et al (2015) L'abri pendimoun (Castellar, Alpes-Maritimes): Nouvelles données sur l'évolution du couvert forestier et l'exploitation du milieu au néolithique (5 800-2 000 ans cal. BCE). Quaternaire 26:279-292

Beeching A (2002) La fin du Chasséen et le Néolithique final dans le bassin du Rhône moyen. In: Ferrari A, Visentini P (eds) Il declino del mondo neolitico. Ricerche in Italia centro-settentrionale fra aspetti peninsulari, occidentali e nord-alpini (Pordenone,
2001). Quaderni del Museo Archeologico del Friuli Occidentale 4. Museo delle Scienze, Pordenone, pp 67-83

Beeching A (2015) Saint-Paul-Trois-Châteaux (Drôme). Site funéraire du Néolithique moyen chasséen. Etat préliminaire de la publication. In: Beeching A, Brochier JL (eds) Les Grands sites de terrasses chasséens dans le contexte des recherches rhodaniennes. ACR, Rapports de 2005 et 2006, CAPRA, Valence

Beeching A, Brochier J-L (2011) De l'environnement au territoire néolithiques dans le bassin rhodanien. In: Kourtessi-Philippakis G, Treuil R (eds) Archéologie du territoire: de l'Egée au Sahara. Publications de la Sorbonne, Paris, pp 137-153

Beeching A, Cordier F (1997) Saint-Paul-Trois-Chateaux, Les Moulins. Site sepulcral chasséen et silos medievaux. Fouille de sauvetage 1984-1985. Centre d'Archéologie Préhistorique de Valence, Valence

Beeching A, Cordier F (2004) Saint-Paul-Trois-Châteaux: Les Moulins-Carrefour de 1'Europe. In: Bilan scientifique. Région Rhône-Alpes 2001, Ministère de la Culture, Lyon, pp 68-69

Beeching A, Berger JF, Brochier J-L et al (2000) Chasséens: agriculteurs ou éleveurs, sédentaires ou nomades? Quels types de milieux, d'économies et de sociétés? In: Leduc M, Valdeyron N, Vaquer J (eds) Sociétés et Espaces, Rencontres Méridionales de Préhistoire Récente, 3ème session, Toulouse, 1998. Archives d'Écologie Préhistorique, Toulouse, pp 59-79

Beeching A, Brochier JL, Rimbault S, Vital J (2010) Les sites à fosses circulaires du néolithique et de l'âge du bronze ancien en moyenne vallée du Rhône: approches typologiques et fonctionnelles, implications économiques et sociales. In: Beeching A, Thirault E, Vital J (eds) Economie et société à la fin de la préhistoire. Actualité de la recherche. Actes des 7e rencontres méridionales de préhistoire récente. Maison de l'Orient et de la Méditerranée Jean Pouilloux, Lyon, pp 147-169

Beeching A, Cordier F, Thiercelin F (1986) Découverte et fouille partielle du village chasséen de Saint-Paul-Trois-Châteaux "Les Moulins" (Drôme). In: Arenera: Actes des rencontres "Néolithique de Rhône-Alpes". Univ. Lumière Lyon II, Centre d'Archéol. Préhist. de Valence, Valence, pp 27-31

Beeching A, Nicod P-Y, Thiercelin F, Voruz J-L (1997) Le Saint-Uze, un style céramique non-chasséen du cinquième millénaire dans le bassin rhodanien. In: Constantin C, Mordant D, Simonin D (eds) La Culture de Cerny: nouvelle économie, nouvelle société au Néolithique. Association pour la promotion de la recherche archéologique en Ile-de-France. APRAIF, Nemours, pp 575-592

Berger JF, Shennan S, Woodbridge J et al (2019) Holocene land cover and population dynamics in Southern France. Holocene 29:776798. https://doi.org/10.1177/0959683619826698

Binder D, Brochier EJ, Duday H et al (1993) L'abri Pendimoun à Castellar (Alpes-Maritimes). Nouvelles données sur le complexe culturel de la céramique imprimée méditerranéenne dans son contexte stratigraphique. Gall Préhistoire 35:177-251. https:// doi.org/10.3406/galip.1993.2087

Binder D, Cade C, Desse-Berset N et al (2004) Un chantier archéologique à la loupe: Villa Giribaldi. In: Nice: [catalogue d'exposition 23 octobre 2004-4 janvier 2005]. Nice-Musées, Nice

Binder D, Lepère C (2014) From impresso-cardial to SMP and chassey in provence. In: Brea MB, Maggi R, Manfredini A (eds) Atti del convegno: Il pieno sviluppo del Neolitico in Italia: Museo Archeologico del Finale-Finale Ligure Borgo, 8-10 giugno 2009. Istituto Internazionale di Studi Liguri, Bordighera, pp 21-29

Bogaard A, Charles M, Twiss KCC et al (2009) Private pantries and celebrated surplus: storing and sharing food at Neolithic Çatalhöyük, Central Anatolia. Antiquity 83:649-668. https://doi. org/10.1017/s0003598x00098896

Bouby L (1999) Rapport d'étude carpologique. In: Vignaud A (ed) Les jardins de Vert Parc, Castelnau-le-Lez, 34. Un habitat 
Néolithique moyen de culture chasséenne, Document Final de Synthèse, Ministère de la Culture, SRA Languedoc-Roussillon, Association pour les fouilles archéologiques nationales (AFAN), pp 77-80

Bouby L (2009) Les restes carpologiques des couches 60 à 47. In: Voruz J-L, Bonnardin S, Chaix L et al (eds) La grotte du Gardon (Ain), vol 1, le site et la séquence néolithique des couches 60 à 47. (Archives d'Écologie Préhistorique) Ecole des Hautes Etudes en Sciences Sociales, Toulouse, pp 227-230

Bouby L, Léa V (2006) Exploitation de la vesce commune (Vicia sativa L.) au Néolithique moyen dans le Sud de la France. Données carpologiques du site de Claparouse (Lagnes, Vaucluse). CR Palevol 5:973-980. https://doi.org/10.1016/j.crpv.2006.07.007

Bouby L, Dietsch-Sellami M-F, Martin L et al (2018) Ressources végétales et économie de subsistance au Néolithique en France (6000-2000 av. J.-C.). In: Guilaine J, Garcia D (eds) La Protohistoire de la France. Hermann, Paris, pp 141-152

Bouby L, Marinval P, Durand F et al (2020a) Early Neolithic ( ca. $5850-4500 \mathrm{cal}$ BC ) agricultural diffusion in the Western Mediterranean: an update of archaeobotanical data in SW France. PLoS One 15:1-26. https://doi.org/10.1371/journal.pone.02307 31

Bouby L, Marinval P, Rovira N (2020b) Late Neolithic plant subsistence and farming activities on the southern margins of the Massif Central (France). Holocene 30:599-617. https://doi. org/10.1177/0959683619895576

Bronk Ramsey C (2017) OxCal Program, Version 43. Oxford Radiocarbon Accelerator Unit, University of Oxford, Oxford

Buxó R (2006) Les restes des semences et fruits archéologiques de la grotte de Montou. Études Roussillonnaises 22:33-42

Cappers R, Heinrich F, Kaaijk S et al (2013) Barley revisited: production of barley bread in Umm Mawagir (Kharga Oasis, Egypt). In: Accetta K, Fellinger R, Gonçalves PL et al (eds) Current Research in Egyptology. Proceedings of the Fourteenth Annual Symposium, University of Cambridge 2013. Oxbow, Oxford, pp 49-63

Contreras DA, Hiriart E, Bondeau A et al (2018) Regional paleoclimates and local consequences: Integrating GIS analysis of diachronic settlement patterns and process based agroecosystem modeling of potential agricultural productivity in Provence (France). PLoS One 13:1-27. https://doi.org/10.1371/journ al.pone. 0207622

Convertini F, Georjon C (2018) Le Champ du Poste (Carcassonne, Aude). Une succession d'occupations du début du Néolithique moyen à l'âge du Bronze ancien. Archives d'Ecologie Préhistorique, Toulouse

De Vareilles A, Bouby L, Jesus A et al (2020) One sea but many routes to sail. The early maritime dispersal of Neolithic crops from the Aegean to the western Mediterranean. J Archaeol Sci Rep 29:102140. https://doi.org/10.1016/j.jasrep.2019.102140

Delhon C, Thiébault S, Berger JF (2009) Environment and landscape management during the Middle Neolithic in Southern France: Evidence for agro-sylvo-pastoral systems in the Middle Rhone Valley. Quat Int 200:50-65. https://doi.org/10.1016/j.quain t.2008.05.008

Denaire A, van Willigen S (2020) Les structures et leur attribution culturelle. In: van Willigen S, Bailly M, Röder B, et al. (eds) Les Bagnoles à L'Isle-sur-la-Sorgue (Vaucluse)—le Néolithique moyen et les occupations postérieures (âge du Bronze, âge du Fer et Antiquité). Presses Universitaires de Provence, Aix-enProvence, pp 101-116

Denaire A, Doppler T, Nicod P-Y, van Willigen S (2011) Espaces culturels, frontières et interactions au 5ème millénaire entre la plaine du Rhin supérieur et les rivages de la Méditerranée. Annu d'Archéologie Suisse 94:21-59
Figueiral I (2018) Les restes végétaux carbonisés. In: Convertini F, Georjon C (eds) Le Champ du Poste (Carcassonne, Aude) Une succession d'occupations du début du Néolithique moyen à l'âge du Bronze ancien. Archives d'Ecologie Préhistorique, Toulouse, pp 239-242

Figueiral I (2012) 1(5), pp. 4. Les vestiges végétaux carbonisés. In: Vergély H, Haurillon R, Sanchez G (eds) Les occupations humaines du Barreau de la Devèze Sud, vol 1. HAL CCSD, Lyon, pp 402-406

Figueiral I, Séjalon P (2014) Archaeological wells in southern France: Late Neolithic to Roman plant remains from Mas de Vignoles IX (Gard ) and their implications for the study of settlement, economy and environment. Environ Archaeol 19:23-38

Fuller DQ, Stevens C, McClatchie M (2014) Routine activities, tertiary refuse and labor organization: social inferences from everyday archaeobotany. In: Savard M, Lancelotti C, Madella M (eds) Ancient plants and people, contemporary trends in archaeology. University of Arizona Press, Tucson, pp 174-217

Gernigon K (2014) Le Chasséen entre temps et espace: 20 ans de périodisations des assemblages céramiques et le retour de l'identité chasséenne. In: Sénépart I, Leandri F, Cauliez J, et al. (eds) Chronologie de la Préhistoire récente dans le Sud de la France Actualité de la recherche, Actes des 10e Rencontres méridionales de Préhistoire récente Porticcio (20) - 18 au 20 octobre 2012. Archives d'Ecologie Préhistorique, Toulouse, pp 37-61

Gilabert C (2009) Les structures en creux dans le Néolithique final provençal: synthèse et approche méthodologique. In: Beeching A, Sénépart I (ed) De la maison au village - L'habitat néolithique dans le Sud de la France et le Nord-Ouest méditerranéen Actes de la table ronde des 23 et 24 mai 2003, Marseille/Musée d'Histoire de la Ville de Marseille. (Mémoire Société Préhistorique Française 48) Société Préhistorique Française, Paris, pp 285-300

Giligny F, Sénépart I (2018) Construire et habiter au Néolithique. In: Guilaine J, Garcia D (eds) La Protohistoire de la France. Hermann, Paris, pp 27-51

Hajnalová M, Dreslerová D (2010) Ethnobotany of einkorn and emmer in Romania and Slovakia: towards interpretation of archaeological evidence. Pamatky Archeol 101:169-202

Heinz C, Ruas M-P, Vaquer J (1992) La grotte de l'Abeurador (FélinesMinervois, Hérault): paléoécologie d'après l'anthracologie et la carpologie. Bull Soc Bot Fr Actual Bot 139:465-482. https://doi. org/10.1080/01811789.1992.10827121

Herbig VC, Maier U, Stäuble H, Elburg R (2013) "Neolithische Füllhörner" Archäobotanische Untersuchungen in fünf linienbandkeramischen Brunnen in Westsachsen. Offa 69(70):265-293

Hillman GC, Mason S, de Moulins D, Nesbitt M (1996) Identification of archaeological remains of wheat: the 1992 London workshop. Circaea 12:195-209

Jacomet S (2006) Identification of cereal remains from archaeological sites. IPAS Basel University, Basel

Jacomet S (2007) Neolithic plant economies in the northern Alpine Foreland from 5500-3500 cal. BC. In: Colledge S, Conolly J (eds) The origins and spread of domestic plants in southwest Asia and Europe. Left Coast Press, Walnut Creek, pp 221-258

Jacomet S (2013) Archaeobotany: analyses of plant remains from waterlogged archaeological sites. In: Menott F, O'Sullivan A (eds) The Oxford handbook of wetland archaeology. Oxford University Press, Oxford, pp 497-514

Jacomet $S$ (2014) crop diversity in Southwestern central Europe from the Neolithic onwards. In: Chevalier A, Marinova E, PeñaChocarro L (eds) Plants and people choices and diversity through time. Oxbow Books, Oxford, pp 82-139

Jacomet S (2020) Environnement végétal naturel et paysage. In: van Willigen S, Bailly M, Röder B, et al. (eds) Les Bagnoles à 
L'Isle-sur-la-Sorgue (Vaucluse) - le Néolithique moyen et les occupations postérieures (âge du Bronze, âge du Fer et Antiquité). Presses Universitaires de Provence, Aix-en-Provence, pp 60-77

Jesus A, Tereso JP, Gaspar R (2020) Interpretative trajectories towards the understanding of negative features using Terraço das Laranjeiras Bronze Age site as a case study. J Archaeol Sci Rep 30:102222. https://doi.org/10.1016/j.jasrep.2020.102222

Jones G (1990) The application of present-day cereal processing studies to charred archaeobotanical remains. Circaea 6:91-96

Jones G, Wardle K, Halstead P, Wardle D (1986) Crop storage at Assiros. At a site in northern Greece charred fragments of grain from crop new light on how the majestic Bronze Age Mycenaean palaces arose. Sci Am 254:96-103

Kreuz A (1990) Searching for 'single-activity refuse' in Linearbandkeramik settlements. An archaeobotanical approach. In: Robinson DE (ed) Experimentation and reconstruction in environmental archaeolology. Oxbow Books, Oxford, pp 63-74

Kreuz A, Schäfer E (2002) A new archaeobotanical database program. Veget Hist Archaeobot 11:177-180. https://doi.org/10.1007/ s003340200019

Laghetti G, Fiorentino G, Hammer K, Pignone D (2009) On the trail of the last autochthonous Italian einkorn (Triticum monococcum L.) and emmer (Triticum dicoccon Schrank) populations: a mission impossible? Genet Resour Crop Evol 56:1,163-1,170. https:// doi.org/10.1007/s10722-009-9439-x

LaMotta VM, Schiffer MB (2002) Formation processes of house floor assemblages. In: Allison PM (ed) The archaeology of household activities. Routledge, London, pp 19-29

Magny M, Haas JN (2004) A major widespread climatic change around 5300 cal. yr BP at the time of the Alpine Iceman. J Quat Sci 19:423-430

Maier U (2001) Untersuchungen in der neolithischen Ufersiedlung Hornstaad-Hörnle IA am Bodensee. In: Maier U, Vogt R (eds) Siedlungsarchäologie im Alpenvorland VI: Botanische und pedologische Untersuchungen zur Ufersiedlung Hornstaad-Hörnle IA. (Forschungen und Berichte zur Vor- und Frühgeschichte in Baden-Württemberg 74) Theiss, Stuttgart

Marinval P (1988a) L'alimentation végétale en France: du mésolithique jusqu'à l'âge du fer. Editions du Centre nationale de la recherche scientifique, Paris

Marinval P (1988b) Cueillette, agriculture et alimentation végétale de l'epipaléolithique jusqu' au 2e âge du fer en France méridionale: apports palethnographiques de la carpologie. École de Hautes Études en Sciences Sociales, Paris

Marinval P (2003) L'ensemble carpologique du site bizien de la Salle (Carcassonne, Aude). Bull Soc Prehist Fr 100:353-355

Martin L (2012) Analyse carpologique du puits. Néolithique récent ST2096. In: Remicourt M, Andrieu-Ponel V, Audibert C et al (eds) Les occupations pré et protohistoriques du Clos de Roque, à Saint-Maximin-la-Sainte Baume. Rapport Final d'Opération 1. Paléotime, Villard-de-Lans, pp 242-246

Martin L (2014) Premiers paysans des Alpes. Presses Universitaires de Rennes, Rennes, Alimentation végétale et agriculture au Néolithique

Martin L, Bouby L, Marinval P et al (2016) L'exploitation des ressources végétales durant le Chasséen: un bilan des données carpologiques en France entre 4400 et 3500 avant notre ère. In: Perrin T, Chambon P, Gibaja JF, Goude G (eds) Le Chasséen, des Chasséens... Retour sur une culture nationale et ses parallèles: Sepulcres de fossa, Cortaillod, Lagozza Colloque international de Paris, 18-20 novembre 2014. Archives d'Écologie Préhistorique, Toulouse, pp 259-272

Martin L, Jacomet S, Thiebault S (2008) Plant economy during the Neolithic in a mountain context: the case of "le Chenet des Pierres" in the French Alps (Bozel-Savoie, France). Veget
Hist Archaeobot 17:113-122. https://doi.org/10.1007/s0033 4-008-0191-5

Martínez-Grau H, Antolín F, van Willigen S (2020) Néolithique moyen type La Roberte et Néolithique moyen type Chassey sur le site des Bagnoles: relations spatiales et chronologiques. In: van Willigen S, Bailly M, Röder B, et al. (eds) Les Bagnoles à L'Isle-surla-Sorgue (Vaucluse)—le Néolithique moyen et les occupations postérieures (âge du Bronze, âge du Fer et Antiquité). Presses Universitaires de Provence, Aix-en-Provence, pp 270-278

Mestres J, Tarrús J (2016) Las estructuras de hábitat en Catalunya durante el Neolítico medio: entre el Chassey y los Sepulcres de Fossa. In: Perrin T, Chambon P, Gibaja JF, Goude G (eds) Le Chasséen, des Chasséens... Retour sur une culture nationale et ses parallèles: Sepulcres de fossa, Cortaillod, Lagozza Colloque international de Paris, 18-20 novembre 2014. Archives d'Écologie Préhistorique, Toulouse, pp 289-302

Pala M, Stockle CO, Harris HC (1996) Simulation of Durum wheat (Triticum turgidum ssp. durum) growth under different water and nitrogen regimes in a Mediterranean environment using CropSyst. Agric Syst 51:147-163. https://doi.org/10.1016/0308521X(95)00043-5

Peña-Chocarro L, Zapata L, González Urquijo JE, Ibáñez JJ (2009) Einkorn (Triticum monococcum L.) cultivation in mountain communities of the western Rif (Morocco): an ethnoarchaeological project. In: Fairbairn AS, Weiss E (eds) From foragers to farmers: papers in honour of Gordon C. Hillman. Oxbow, Oxford, pp 103-111

Phillips P (1982) The Middle Neolithic in Southern France: Chasséen farming and culture process. (British Archaeological Reports International Series S142) BAR, Oxford

Popper V (1988) Selecting quantitative measurements in paleoethnobotany. In: Hastorf C, Popper V (eds) Current paleoethnobotany: analytical methods and cultural interpretations of archaeological plant remains. University of Chicago Press, Chicago, pp 53-71

Prats G (2017) L'emmagatzematge en sitja entre el neolític i l'època ibèrica (del 5500 ANE al I ANE). Aproximació socioeconòmica a les comunitats del nord-est de la Península Ibèrica, Unpublished doctoral thesis, Universitat de Lleida

Prats G, Antolín F, Alonso N (2020) A socioeconomic analysis of the changes in underground storage practices in the Northwestern Mediterranean Arc: from the earliest farmers to the first urban centres. Antiquity 94:653-668

Reed K (2016) Archaeobotany in Croatia: an overview. Vamz 49:7-28

Reimer PJ, Bard E, Bayliss A et al (2013) IntCal13 and Marine13 radiocarbon age calibration curves $0-50,000$ years cal BP. Radiocarbon 55:1,869-1,887

Rottoli M (1993) Analisi paletnobotaniche: prime risultanze, "La Marmotta”, Anguillara Sabazia (RM), Scavi 1989, Appendice 1, Un abitato perilacustre di età neolitica. Bull Paletnol Ital Roma, Nuova Ser II 84:305-315

Rottoli M, Castiglioni E (2009) Prehistory of plant growing and collecting in northern Italy, based on seed remains from the early Neolithic to the Chalcolithic (c. 5600-2100 cal B.C.). Veget Hist Archaeobot 18:91-103. https://doi.org/10.1007/s0033 4-007-0139-1

Rousselet O (2011) Analyse carpologique. In: Sendra B, Gourlin B, Cockin G (eds) ZAC Saint-Antoine 2. Saint-Aunès (Hérault), Languedoc-Roussillon. Rapport final d'opération. Fouilles archéologiques préventives, Oxford Archéologie Méditerranée, Service Régional de l' Archéologie de Languedoc-Roussillon, pp 264-272

Saintot S, Le Barrier C, Cabanis M (2009) L'habitat chasséen de Champ Madame et Artière-Ronzière à Beaumont (Puyde-Dôme). Structuration, architecture et fonction du bâtiment 3. In: Beeching $\mathrm{A}$, Senépart I (eds) De la maison au village. L'habitat néolithique dans le Sud de la France et le Nord-Ouest méditerranéen, 
actes de la table ronde (Marseille, 23-24 mai 2003). (Mémoires de la Société préhistorique française 48) Société préhistorique française, Paris, pp 99-121

Sargiano J-P, van Willigen S, D'Anna A et al (2010) Les Bagnoles à l'Isle-sur-la-Sorgue (Vaucluse). Aspects nouveaux dans le Néolithique moyen du midi de la France. Gallia Préhistoire 52:193-239

Savard M (2000) Etude de l'assemblage carpologique de la Baume de Fontbrégoua (Var) du Paléolithique final au Chasséen récent. Mémoire de DEA: Environnement et archéologie: Paris 1

Schiffer MB (1991) Formation processes of the archaeological record, 2nd edn. University of New Mexico Press, Albuquerque

Schlumbaum A, Jacomet S, Neuhaus JM (1998) Coexistence of tetraploid and hexaploid naked wheat in a Neolithic lake dwelling of Central Europe: evidence from morphology and ancient DNA. J Archaeol Sci 25:1,111-1,118. https://doi.org/10.1006/ jasc. 1998.0338

Sendra B, Gourlin B, Cockin G (2011) ZAC Saint-Antoine 2. Saint-Aunès (Hérault), Languedoc-Roussillon. Rapport final d'opération. Fouilles archéologiques préventives Oxford Archéologie Méditerranée, Service Régional de l'Archéologie de Languedoc-Roussillon

Sénépart I, Leandri F, Cauliez J et al (2014) Chronologie de la Préhistoire récente dans le Sud de la France. Acquis 1992-2012. Actualité de la recherché. Actes des 10e Rencontres Méridionales de Préhistoire Récente, Porticcio, 18 au 20 octobre 2012. Archives d'Ecologie Préhistorique, Toulouse

Sharples NM (1991) Maiden Castle: excavations and field survey 1985-6. English Heritage, London

Sigaut F (1988) A method for identifying grain storage techniques and its application for European agricultural history. In: Lerche G, Fenton A, Steensberg A (eds) Tools and tillage. National Museum of Denmark, Copenhagen, pp 3-32

Steiner BL, Antolín F, Jacomet S (2015) Testing of the consistency of the sieving (wash-over) process of waterlogged sediments by multiple operators. J Archaeol Sci Rep 2:310-320. https://doi. org/10.1016/j.jasrep.2015.02.012

Tegel W, Elburg R, Hakelberg D et al (2012) Early Neolithic water wells reveal the world's oldest wood architecture. PLoS One 7:e51374. https://doi.org/10.1371/journal.pone.0051374

Thiébault S, Terral J-F, Marinval P (2004) Gestion et exploitation d'un territoire au Néolithique: le cas de Giribaldi (Nice, AlpesMaritimes). L'apport des macrorestes végétaux. In: Bodu P, Constantin C (eds) Approches fonctionnelles en préhistoire, Actes du XXVe congrès SPF, Nanterre, nov. 2000. Société Préhistorique Française, Nanterre, pp 325-333

Thirault É, Remicourt M (2014) Les puits à eau néolithiques dans le Sud de la France: une question à creuser . In Sénépart I, Billard $\mathrm{C}$, Bostyn $\mathrm{F}$ et al (eds) Méthodologie des recherches de terrain sur la Préhistoire récente en France. Nouveaux acquis, nouveaux outils, 1987-2012. Archives d'Ecologie Préhistorique, Toulouse, pp 231-250

Tolar T, Jacomet S, Velušček A, Čufar K (2010) Recovery techniques for waterlogged archaeological sediments: a comparison of different treatment methods for samples from Neolithic lake shore settlements. Veget Hist Archaeobot 19:53-67. https://doi. org/10.1007/s00334-009-0221-y

Toulemonde F, Durand F, Berrio L et al (2015) Records of "new" glume wheat in France: a review. Veget Hist Archaeobot 24:197206. https://doi.org/10.1007/s00334-014-0479-6
Van der Veen M, Fieller N (1982) Sampling seeds. J Archaeol Sci 9:287-298. https://doi.org/10.1016/0305-4403(82)90024-3

Van Willigen S, André G, Antolín F et al (2020) Déroulement des opérations et moyens mis en œuvre. In: van Willigen S, Bailly M, Röder B, et al. (eds) Les Bagnoles à L'Isle-sur-la-Sorgue (Vaucluse)—le Néolithique moyen et les occupations postérieures (âge du Bronze, âge du Fer et Antiquité). Presses Universitaires de Provence, Aix-en-Provence, pp 87-100

Van Willigen S, Antolín F, Brochier J et al (2020) Les apports du site pour la connaissance du Néolithique moyen. In: van Willigen S, Bailly M, Röder B, et al. (eds) Les Bagnoles à L'Isle-surla-Sorgue (Vaucluse)—le Néolithique moyen et les occupations postérieures (âge du Bronze, âge du Fer et Antiquité). Presses Universitaires de Provence, Aix-en-Provence, pp 281-352

Van Willigen S, Brochier JÉ, Renault S, Sargiano J-P (2014) Chronologie relative et chronologie absolue du Néolithique moyen dans le sud-est de la France: l'apport de l'analyse des données et de la modélisation chronologique bayésienne. In: Sénépart I, Leandri F, Cauliez J, Perrin T, Thirault É (eds) Chronologie de la Préhistoire récente dans le Sud de la France: Actualité de la recherche. (Actes des 10e Rencontres méridionales Préhistoire récente Porticcio 20), 18 au 20 octobre 2012. Toulouse, Archives d'Ecologie Préhistorique, pp 63-74

Vandorpe P, Jacomet S (2007) Comparing different pre-treatment methods for strongly compacted organic sediments prior to wetsieving: a case study on Roman waterlogged deposits. Environ Archaeol 12:207-214. https://doi.org/10.1179/174963107x22646 2

Vaquer J (2014) Les pratiques funéraires au Néolithique moyen dans le Midi de la France. Riv Sci Preist 64:5-24

Vaquer J, Jedikian G, Carrère I, Marinval P (2003) La Salle, Carcassonne (Aude). Un habitat de plein air du groupe de Bize. Bull Soc Préhist Fr 100:323-351

Vergély H, Haurillon R, Sanchez G (2012) Les occupations humaines du Barreau de la Devèze Sud: autoroute A75, section Béziers-Pézenas, Hérault, rapport final d'opération. Fouille archéologique, Inrap Meditérranée Béziers

Vignaud A (2003) Les jardins de Vert Parc (Castelnau-le-Lez, Hérault): un habitat néolithique moyen de culture chasséenne. In: Gascó J, Gutherz X, Labriffe P-A (eds) Temps et espaces culturels: du 6e au 2e millénaire en France du Sud: Actualité de la recherche. (Monographie d'Archéologie Méditerranéenne 15) Association pour le Développement de l'Archéologie en Languedoc-Roussillon, Lattes, pp 397-400

Vital J, Bouby L, Jallet F, Rey P-J (2007) Un autre regard sur le gisement du boulevard périphérique nord de Lyon (Rhône) au Néolithique et à l'âge du Bronze, secteurs 94.1 et 94.8. Gallia Préhistoire 49:1-126

Zohary D, Hopf M, Weiss E (2012) Domestication of plants in the Old World: the origin and spread of domesticated plants in Southwest Asia, Europe, and the Mediterranean Basin. Oxford University Press, Oxford

Publisher's Note Springer Nature remains neutral with regard to jurisdictional claims in published maps and institutional affiliations. 